\title{
Molecular fingerprinting of the myxozoan community in common carp suffering Swim Bladder Inflammation (SBI) identifies multiple etiological agents
}

\author{
Astrid S Holzer ${ }^{1 *}$, Ashlie Hartigan ${ }^{1}$, Sneha Patra ${ }^{1,2}$, Hana Pecková ${ }^{1}$ and Edit Eszterbauer ${ }^{3}$
}

\begin{abstract}
Background: Swim bladder inflammation (SBI) is an important disease of common carp fingerlings in Central Europe. In the 1980s, its etiology was ascribed to multicellular proliferative stages of the myxozoan parasite Sphaerospora dykovae (formerly S. renicola). S. dykovae was reported to proliferate in the blood and in the swim bladder prior to the invasion of the kidney, where sporogony takes place. Due to the presence of emerging numbers of proliferative myxozoan blood stages at different carp culture sites in recent years we analysed cases of $\mathrm{SBI}$, for the first time, using molecular diagnostics, to identify the myxozoan parasites present in diseased swim bladders.
\end{abstract}

Methods: We amplified myxozoan SSU rDNA in a non-specific approach and compared the species composition in swim bladders at culture sites where carp demonstrated 1. No signs of SBI, 2. Minor pathological changes, and 3. Heavy SBI. Based on DNA sequences, we determined the localisation and distribution of the most frequent species by in situ hybridisation, thereby determining which myxozoans are involved in SBI.

Results: Large multicellular myxozoan swim bladder stages characterised heavy SBI cases and were identified as S. dykovae, however, blood stages were predominantly represented by Sphaerospora molnari, whose numbers were greatly increased in carp with mild and heavy SBI, compared with SBI-free fish. S. molnari was found to invade different organs and cause inflammatory changes also in the absence of S. dykovae. One site with mild SBI cases was characterised by Buddenbrockia sp. infection in different organs and a general granulomatous response.

Conclusions: We provide evidence that the etiology of SBI can vary in relation to culture site and disease severity and that emerging numbers of S. molnari in the blood represent an important co-factor or precondition for SBI.

Keywords: Cyprinus carpio carpio, Swim bladder inflammation, Fish disease, Myxozoa, Molecular diagnostics, Ribosomal DNA, In situ hybridisation

\section{Background}

In common carp, Cyprinus carpio carpio L. Swim Bladder Inflammation (SBI) of fingerlings is an acute and severe disease of economic impact in Central Europe [1]. The first signs of SBI include dilated blood vessels and haemorrhages on the swim bladder. In acute SBI, the epithelium of the swim bladder becomes multilayered

\footnotetext{
*Correspondence: astrid.holzer@paru.cas.cz

'Institute of Parasitology, Biology Centre of the Academy of Sciences of the Czech Republic, Branišovská 31, České Budějovice, Czech Republic Full list of author information is available at the end of the article
}

and edematous. As the disease progresses, lymphocytes infiltrate the bladder wall and surrounding areas and secondary infections occur (reviewed in [1]). Mortalities can affect up to $100 \%$ of carp fingerling stocks in Central Europe [2].

Research into SBI first intensified in the 1980s, when the myxozoan Sphaerospora dykovae (Lom and Dyková, 1982) (previously S. renicola) was identified as a key player in the etiology of the disease [1,3-7]. Myxozoans are diverse and widely distributed microscopic parasites belonging to the Cnidaria [8] that occur in a variety of 
aquatic environments and are known for the diseases they can cause in wild and cultured fish.

Three different life cycle stages of $S$. dykovae were described in common carp: 1. Multicellular, proliferative stages floating in the blood (C-stages, first described by Csaba [9]), 2. Multicellular, histozoic stages in the swim bladder (K-stages, first described by Körting [4] and Kovács-Gayer [5]), and 3. Spore-forming plasmodia in the renal tubules $[3,10]$. K-stages cause haemorrhages and necrosis not only in the swim bladder but also in the rete mirabile of the eye [11]. The link between C-, $\mathrm{K}$ - and intratubular stages was made based on their similar morphological characteristics and development, their simultaneous occurrence in infected fish and based on experimental trials focusing on the transmission of $\mathrm{C}$ - and K-stages from infected fish to SPF receptor fish. However, proliferative cell-in-cell stages of myxozoans offer little anatomical differences to distinguish between taxa, and the transmission of blood stages sometimes resulted in the proliferation of these stages in the blood of receptor fish but spore formation in the kidney was not observed $[3,12,13]$ or spore formation was observed but blood stages remained in the fish thereafter [14], thus leaving some ambiguities.

Using molecular methods, we recently demonstrated that myxozoan blood stages in asymptomatic common carp may belong to at least 7 different myxozoan species [15]. To clarify which myxozoans are present in the swim bladder of carp during clinical SBI and which are responsible for pathological changes we used PCR, DNA sequencing and in situ hybridisation (ISH) to determine parasite identity, number per species and exact location in the swim bladder and in other organs, thus identifying the etiological agents of SBI in common carp based on molecular diagnostics. Furthermore, we monitored the fish in an SBI-enzooic pond continuously throughout the year to better understand the seasonality and temperature dependence of parasite invasion and proliferation of the species involved in SBI in common carp.

\section{Methods}

We pre-screened common carp from $10 \mathrm{~S}$. dykovaeenzooic sites in the Czech Republic and Hungary, between 2011 and 2013 (Table 1), and chose 6 of these for more intensive study of SBI during the summer months (July/August): Two sites without SBI (site 1 and 2), two sites with incipient and chronic SBI cases where swim bladders showed mild changes (dilated capillaries, swim bladder opacity, some haemorrhages; site 3 and 4) and two sites with severe signs of SBI (extensive haemorrhages and thickening of the swim bladder wall; sites 5 and 6). At site 5, blood was collected from carp at monthly intervals throughout 2013, to determine the seasonality of the most important myxozoan blood stages.
From each fish, first, a blood sample was taken with a sterile syringe, thereafter a drop of blood, several gill arches as well as parts of the swim bladder and kidney were examined microscopically in fresh smears, for semiquantitative estimation of infection intensity of $S$. dykovae sporogonic stages in the kidney tubules (rated $0-5$; details see Table 1). DNA was extracted from swim bladders and $4 \mu \mathrm{l}$ blood, using a basic phenol-chloroform protocol. From the swim bladders of the selected sites, myxozoan DNA was amplified in a non-specific approach, a nested PCR assay that targets the SSU rDNA gene region $[15,16]$. Following cloning of the obtained PCR products into the pDrive Vector (Qiagen, Germany) and transformation of TOP10 chemically competent $E$. coli cells (Life Technologies, Czech Republic), 50 clones from each site were sequenced unidirectionally (SEQme; https://www.seqme.eu), using the reverse nested PCR primer, to get an approximation of abundant myxozoans. Thereafter, sequence alignments were performed using Geneious 7.0 (Biomatters Ltd., Auckland, New Zealand) and specific primers were designed/applied for the most abundant myxozoan species (Primo Pro 3.4, Chang Biosciences, http://www.changbioscience.com/primo/ primo.html; Table 2). Primers were 5' DIG labelled (Sigma-Aldrich, http://www.sigmaaldrich.com) and used for in situ hybridisation (ISH) employing a DIG-antiDIGalkaline phosphatase protocol $[17,18]$. PCR assays specific for S. dykovae and Sphaerospora molnari Lom et al., $1983[15,18]$ were used for kidney and blood samples. ISH was performed on formalin-fixed and paraffin embedded histological sections, predominantly of swim bladders but also other organs of fish from the six sites studied during summer.

All animal procedures were performed in accordance with Czech legislation (section 29 of Act No.246/1992 Coll., on Protection of animals against cruelty, as amended by Act No. 77/2004 Coll.). We declare that animal handling complied with the relevant European and international guidelines on animal welfare, namely Directive 2010/63/ EU on the protection of animals used for scientific purposes and the guidelines and recommendations of the Federation of Laboratory Animal Science Associations.

\section{Results}

\section{S. dykovae infections at SBI versus non-SBI sites}

Pre-screening initially focussed on $S$. dykovae infection and showed that prevalences of infection ranged between $8.3 \%$ and $81.8 \%$ (average 57\%) and intensities of infection between 1.3 and 5.0 on a $0-5$ scale (Table 1 ). Infection intensity of $S$. dykovae spore-forming stages in the kidney tubules was high $(>4)$ at sites $2,4,5$ and 6 . At 3 of these sites (4-6), fish showed moderate to strong SBI pathology with mortalities on site whereas carp from site 2 were free from macro- or microscopic pathological 
Table 1 Samples sizes and clinical data from pre-screening of common carp kidneys at 10 S. dykovae-enzooic sites

\begin{tabular}{|c|c|c|c|c|c|c|c|c|}
\hline Pond/Country* & Site $\mathrm{nr}$. & $\mathrm{N}$ kidneys $^{\dagger}$ & $\begin{array}{l}\text { S. dykovae } \\
\text { prevalence }^{\dagger}\end{array}$ & $\begin{array}{c}\text { Average S. dykovae } \\
\text { Intensity }^{\dagger}\end{array}$ & $\begin{array}{c}\text { S. molnari } \\
\text { prevalence }^{\dagger}\end{array}$ & SBIt & $\begin{array}{c}\text { N swim bladders } \\
\text { cloning/ISH }\end{array}$ & $\begin{array}{c}\mathrm{N} \text { monthly blood } \\
\text { samples }\end{array}$ \\
\hline Motovidlo/CZ & - & 24 & $8.3 \%$ & 1.3 & $95.8 \%$ & no & - & - \\
\hline Mala Outrata/CZ & - & 46 & $17.4 \%$ & 1.8 & $87 \%$ & no & - & - \\
\hline Krškovec/CZ & - & 27 & $44.4 \%$ & 3.9 & $48.1 \%$ & no & - & - \\
\hline Tourov/CZ & - & 16 & $25 \%$ & 3.2 & $0 \%$ & no & - & - \\
\hline Šnejdlík/CZ & 1 & 21 & $9.5 \%$ & 2.5 & $57.1 \%$ & no & 8 & - \\
\hline Srdce/CZ & 2 & 20 & $75 \%$ & 4.1 & $25 \%$ & no & 8 & - \\
\hline Vožraly/CZ & 3 & 17 & $29.4 \%$ & 2.7 & $82.4 \%$ & moderate & 15 & - \\
\hline Hortobágy/HU & 4 & 23 & $81.8 \%$ & 4.9 & $100 \%$ & moderate & 17 & - \\
\hline Hluboký/CZ & 5 & 43 & $72.1 \%$ & 5.0 & $100 \%$ & strong & 10 & $354^{\ddagger}$ \\
\hline Százhalombatta/HU & 6 & 7 & $71.4 \%$ & 4.8 & $85.7 \%$ & strong & 13 & - \\
\hline
\end{tabular}

${ }^{*} \mathrm{CZ}=\mathrm{Czech}$ Republic, $\mathrm{HU}=$ Hungary; ${ }^{\dagger}$ Data related to pre-screening of all ponds: based on PCR (infection prevalence) and visual examination (infection intensity); intensity refers to infected fish only, estimated in kidney smears rated 0-5 on basis of the percentage of renal tubules containing parasite stages and their degree of filling (a-small numbers of parasites, b-large sections of tubules filled with parasites, c-lumen of tubules widened by masses of parasites): $1=1-8 \% / a, 2=9-16 \% / a$, $3=17-23 \% / \mathrm{b}, 4=24-39 \% / \mathrm{b}, 5=40-79 \% / \mathrm{c}^{\ddagger}{ }^{\ddagger}$ At least 15 fish per month; sampling conducted $2011-2013$.

changes, despite large parasite loads in the renal tubules. At one further site (site 3) SBI pathology was detected in fish, however, S. dykovae prevalence and intensity of infection was relatively low $(29.4 \%$ and 2.7$)$ when compared with other SBI sites (sites 4-6; 72.1-81.8\% and 4.8-5.0). Due to the results from DNA sequencing all sites were later also screened for infection with $S$. molnari. Fish at all but one site were infected; average prevalence of infection was 73.4\%. Prevalences of S. molnari were highest $(82.4-100 \%)$ at the four SBI sites and at one other site without SBI symptoms (Table 1).

\section{Involvement of different myxozoan species in SBI cases}

Cloning of myxozoan PCR amplicons from swim bladders of carp showed that eight species were abundant, i.e. S. dykovae, S. molnari, Thelohanellus hovorkai Achmerov, 1960, Myxobolus encephalicus Mulsow, 1911, Buddenbrockia sp. (identical with GenBank accession numbers FJ939290, FJ939292-3, KF731702-7), Tetracapsuloides sp. (identical with GenBank accession number KF731716), Hoferellus cyprini Doflein, 1898 and Chloromyxum cyprini Fujita, 1927 (Figure 1). The highest overall percentages of clones were obtained from S. dykovae (average 29\%) and S. molnari (average 28\%). While S. molnari was most prominent at sites with moderate SBI pathology (48-50\%),
S. dykovae clearly dominated the sites with heavy SBI pathology (46-94\%). Buddenbrockia sp. was common at all sites (average 17\%) with most of the clones sequenced from non-SBI sites and from one of the moderate SBI sites (site 3). Myxobolus encephalicus was sequenced from an average of $17 \%$ of all clones and was most common at non-SBI sites as well as at site 4 (moderate SBI). Tetracapsuloides sp., H. cyprini and C. cyprini were not detected at all sites and occurred in a low number of clones (averages 4.5\%, 6\% and 7\%, respectively). T. hovorkai was present only at one site.

In order to determine the exact location and distribution of infectious parasite stages in the tissues of the swim bladders and their relation to host tissue responses we performed ISH on histological sections of swim bladders of carp from the six sites, targeting all species with an important number of clones present in SBI cases, i.e. S. dykovae, S. molnari, Buddenbrockia sp., M. encephalicus and T. hovorkai. ISH showed that only three myxozoans occurred in large numbers within different swim bladder tissue layers and can thus potentially be related to the typical SBI pathology, i.e. S. dykovae, S. molnari and Buddenbrockia sp.

The multicellular myxozoan stages (K-stages), which had been reported in the past and which characterised

Table 2 Specific ISH primers targeting the SSU rDNA gene region of different myxozoan species

\begin{tabular}{|c|c|c|c|}
\hline Species & Primer name & Primer sequence & Origin \\
\hline Sphaerospora dykovae & SdykR & 5'-ACGCAAAGATGCACACACACTGGAC-3' & [15] \\
\hline Sphaerospora molnari & SmSSU1307R & 5'-ACCGTGAGCCACGCGTAATG-3' & [18] \\
\hline Thelohanellus hovorkai & ThoR & 5'-CTATCAAAGCTTCAGGTTGCC-3' & This study \\
\hline Myxobolus encephalicus & MencR & 5'-TACACGCCTCCAACAACGCC-3' & This study \\
\hline Buddenbrockia sp. & BuddR & 5'-AAACGCCTTTCGATTACGG-3' & This study \\
\hline
\end{tabular}




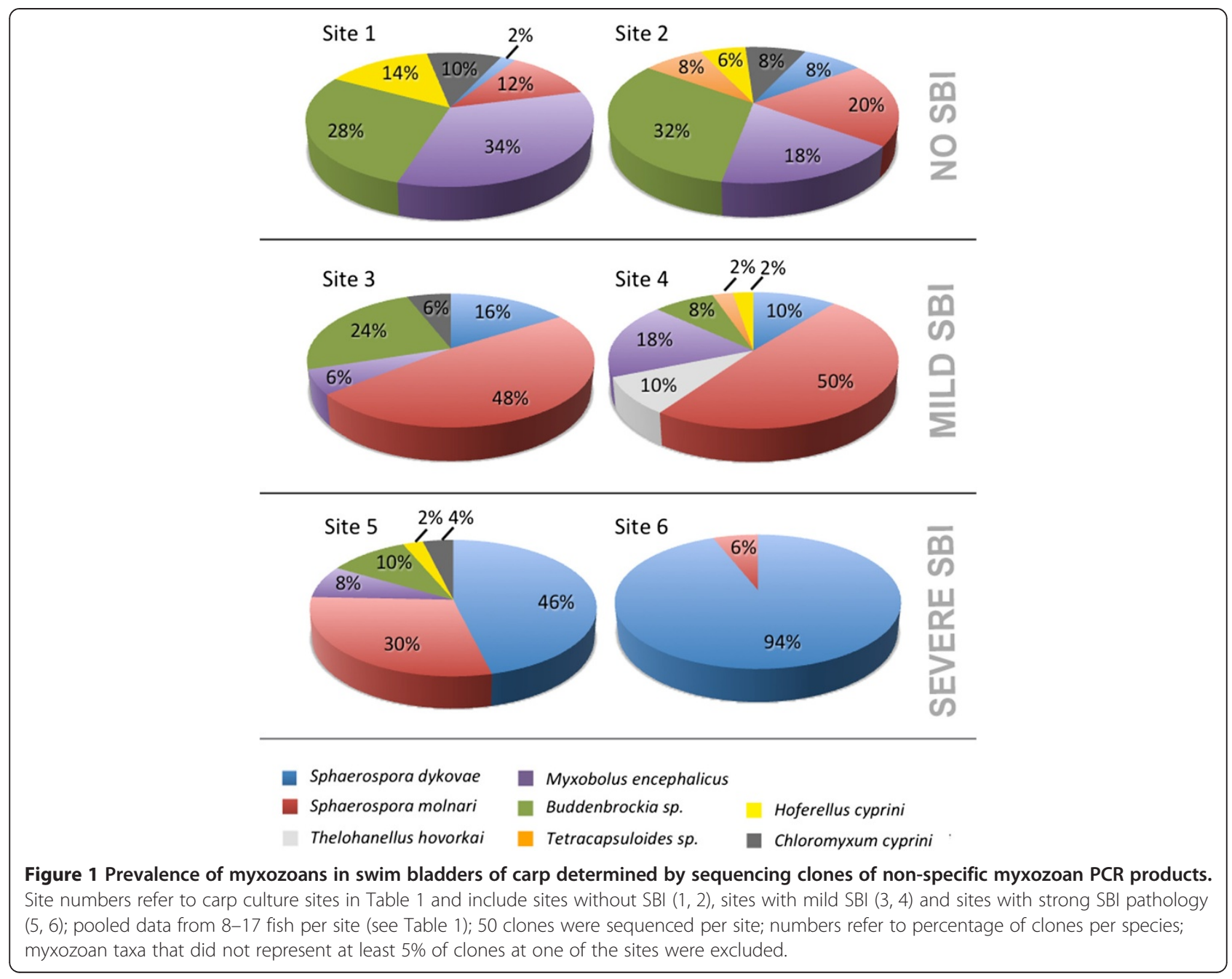

heavy SBI cases in the present study, represented exclusively S. dykovae. K-stages measured 15-47 $\mu \mathrm{m}$ and occupied large areas of the heavily diseased swim bladders with parasites concentrating in and around the blood vessels (Figure 2A-B). Heavy SBI was accompanied by considerable swelling of the kidneys while other haematopoietic organs appeared normal.

In contrast to heavy SBI, moderate SBI cases were characterised by low incidence of $S$. dykovae but surprisingly high numbers of $S$. molnari. Thereby, presporogonic stages of $S$. molnari were considerably smaller $(2-17 \mu \mathrm{m})$ than those of $S$. dykovae (see above) and were not found to accumulate but were dispersed. While most dominant in the blood and strongly vascularised areas of different organs (Figure 2D, E), S. molnari was numerous in all layers of the swim bladder (Figure 2C), the kidney interstitium as well as the rete mirabile and surrounding areas of the eye (Figure 2E) of almost all mild and several heavy SBI cases. At site 4, individual fish with mild SBI pathology demonstrated large numbers of $S$. molnari in the swim bladder in the absence of $S$. dykovae.

Buddenbrockia sp. infection manifested itself in the form of small cell doublets in the vascular system. At site 3, Buddenbrockia sp. occurred in larger numbers in the gills (Figure 2F) and dispersed in the tissues of the swim bladders, the haematopoietic organs and the brain, always in close vicinity to small blood vessels. The increased number of Buddenbrockia sp. stages was related to a general inflammatory response and swelling of all haematopoietic organs (kidney, spleen, liver), which was macroscopically noticeable only at this site. At non-SBI sites, S. molnari and Buddenbrockia sp. occurred almost exclusively intravascularly, while $S$. dykovae was undetectable by ISH.

Independent from the site, multicellular proliferative stages of $M$. encephalicus were rarely detected using ISH but were restricted to the vascular system, while T. hovorkai was found isolated in small spore-forming plasmodia within different connective tissue layers (not shown). 


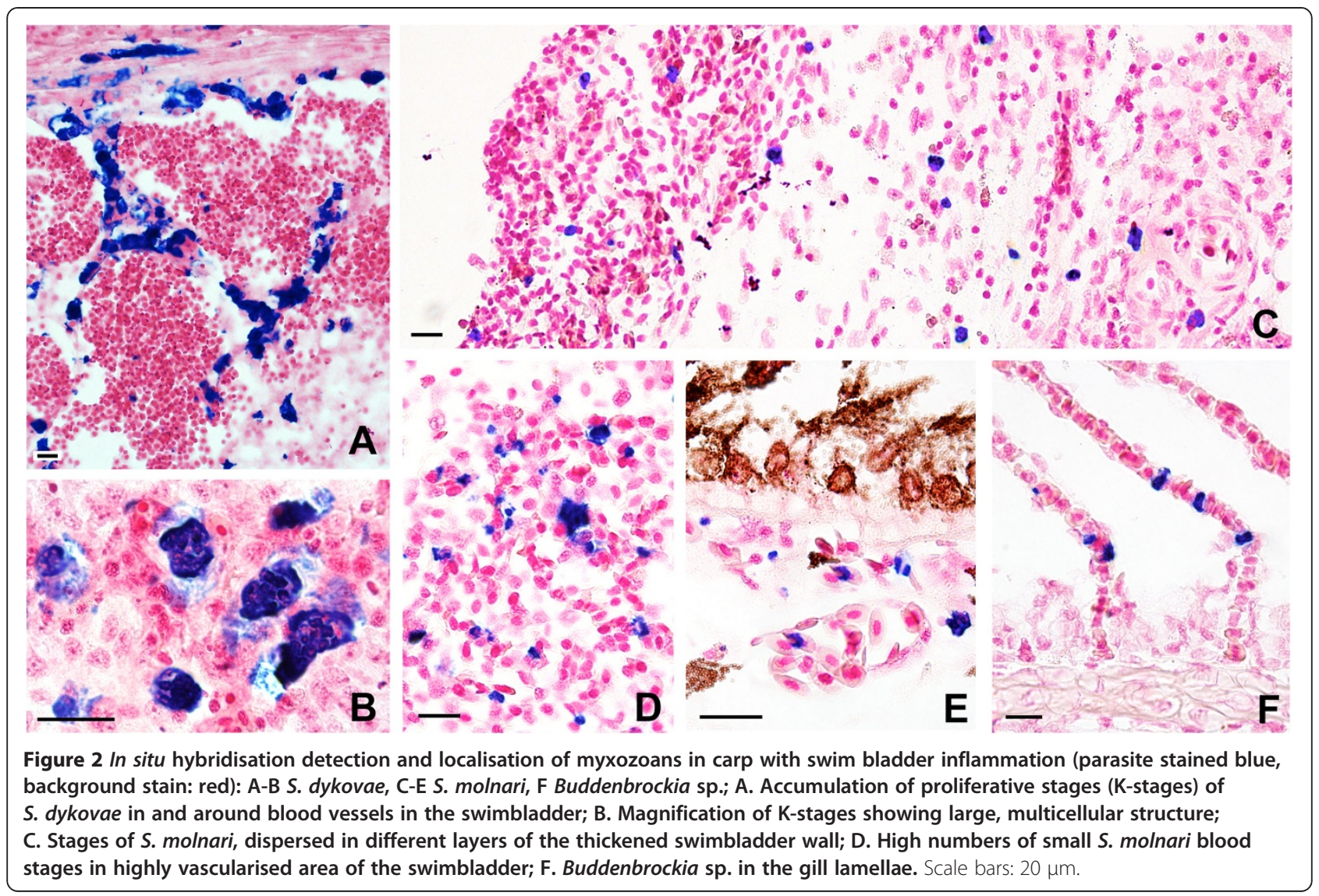

\section{Seasonality of proliferative blood stages of S. dykovae and S. molnari}

The monthly PCR screening of blood samples from carp at site 5 demonstrated that $S$. dykovae blood stages occurred only during late spring/early summer and in a small percentage of fish (4.8-19.2\%, Table 3), despite $72.1 \%$ infection prevalence in the kidney (Table 1). Furthermore, these stages were present only during a very

Table 3 Seasonal prevalence of invasive sphaerosporid proliferative stages in the blood

\begin{tabular}{lcc}
\hline Month* & S. molnari & S. dykovae \\
\hline March & $100 \%$ & $0 \%$ \\
April & $50.3 \%$ & $0 \%$ \\
May & $55.6 \%$ & $4.8 \%$ \\
June & $96.6 \%$ & $19.2 \%$ \\
July & $100 \%$ & $11.1 \%$ \\
August & $100 \%$ & $0 \%$ \\
September & $86.7 \%$ & $5.9 \%$ \\
October & $66.7 \%$ & $0 \%$ \\
November & $40 \%$ & $0 \%$ \\
\hline
\end{tabular}

Data obtained from site 5 (see Table 1). *Data for December, January and February unavailable due to freezing of pond. limited period of time, thus indicating a narrow window of infection of carp with $S$. dykovae, between May and July. In contrast, S. molnari was present in the blood all year, with reduced prevalence in the winter months as well as during April and May, when spore formation was observed in the gills.

\section{Discussion}

Proliferative myxozoan stages were determined as the causative agents of SBI in common carp in Central Europe in the 1980s. They were identified as $S$. dykovae based on morphological similarities and simultaneous occurrence with proliferative C-stages in the blood and spore-forming stages in the kidney, and by experimental infections. Approximately 30 years later, we used molecular diagnostics to reanalyse the etiology of SBI and the identity of the presumed life cycle stages of $S$. dykovae. We developed sensitive and specific assays based on PCR and ISH technology, which allowed us to identify the myxozoans that invade the swim bladder tissues from the circulatory system and that can be related to the typical pathology occurring during SBI in common carp.

We identified the multicellular K-stages reported in the literature e.g. $[4,5,19]$ as $S$. dykovae. However, even though K-stages were present in large numbers at all 
culture sites with heavy SBI cases in the present study, we demonstrate that high prevalence and infection intensity of $S$. dykovae alone is not necessarily a reason to develop pathological changes in the swim bladder (site 2, Table 1). This is supported by the inconsistent detection of K-stages in SBI cases in the past, so that viruses, bacteria and protozoans had been suggested as agents of SBI, reviewed in [1]. Our novel results show that large numbers of $S$. molnari in the blood and in the swim bladder tissues are likely a pre-condition for the development of severe SBI involving S. dykovae or they may cause an SBI that is characterised by a less severe pathology, even in the absence of S. dykovae. S. molnari is a myxozoan that forms spores in the epithelia of the gill filaments and the skin, causing marked dystrophic changes and necrosis $[20,21]$. While we only observed spore formation in the gills in spring, alerting numbers of $S$. molnari blood stages were observed during summer (SBI season). Importantly, while invading predominantly the kidney interstitium [18,22] (identified as S. dykovae in [22] but possibly S. molnari), S. molnari stages were also detected in the tissues of the swim bladder of all SBI carp and at one site (site 4), this was the only parasite detectable by ISH in pathologically modified swim bladders. It cannot be excluded that the pathology detected at site 4 involves a previous $S$. dykovae infection that has been cleared or if the sole cause of the inflammation is $S$. molnari. However, S. molnari was present in clearly elevated numbers at all sites with moderate to heavy SBI conditions when compared with non-SBI sites (Table 1, Figure 1).

We assume that, in the past, the failure to develop S. dykovae infections in the kidney tubules after IP transfection of blood containing C-stages from S. dykovaeinfected carp to SPF receptor fish $[3,12,13]$ likely occurred because most of the blood stages in SBI carp actually represent S. molnari. By transport in the blood stream these stages can reach any tissue and potentially cause pathological effects also in other organs. Due to their concentration in the rete mirabile of the eye it is likely that the pathology ascribed to blood stages of $S$. $d y k o-$ vae, exophthalmia caused by swelling of the choroidal rete mirabile [11], is actually caused by $S$. molnari. We present evidence for year-round proliferation of S. molnari in the blood, with emerging numbers during the summer months, at sites characterised by moderate SBI. We believe that $S$. molnari is a pathogen on the rise as its proliferation in the blood is temperature dependent (unpublished data), although it is unclear whether its multiplication is based solely on temperature increase or on parasite-induced changes in host physiology [23]. However, according to the European Environmental Agency, water temperatures in European freshwater habitats have increased by $1-3^{\circ} \mathrm{C}$ over the last century [24]. At higher temperatures and subsequent lower oxygen levels in stagnant ponds fish may also receive a higher dose of infective spores due to increased ventilation volumes passing through the gills [25]. Comparing S. molnari infection levels with old records is difficult as PCR assays were unavailable at the time, however, in 1983, 70\% (31/44) of stocks were infected with an overall prevalence of $46 \%$ [12] while, 30 years later, we detected the parasite in 90\% (9/10) of stocks and with an overall prevalence of $73.4 \%$.

We found that the prevalence of $S$. molnari blood stages decreases only during winter and during the spore-forming season in spring. In contrast, S. dykovae has a very limited incubation time in the blood, which presumably coincides with the limited presence of fishinfective spore stages in the environment, providing only a small window for the infection of carp, in late spring/ early summer. Our data furthermore show that $S$. molnari proliferates predominantly in the blood and subsequently invades, amongst other organs, the swim bladder tissues. The size of $S$. molnari stages in the swim bladder was the same as that of their blood stages, a size far inferior to that of $S$. dykovae K-stages. This suggests that $S$. molnari does not proliferate once histozoic. In contrast, $S$. dykovae multiplies further in the swim bladder and forms larger parasite stages with tertiary cells [26]. This may explain why $S$. dykovae represents the major contributor to a more severe pathological condition of SBI. S. molnari stages with a histozoic life style were most common in the kidney, the back of the eye and the swim bladder (in this order). These are likely good sites for parasite accumulations due to the occurrence of fine capillary networks (rete mirabile), which slow down the blood flow and trap multicellular parasite stages due to the diameter of the capillaries, allowing them to attach to and pass through the blood vessel walls into the surrounding tissues. S. molnari's site preference for the kidney may furthermore be explained by a recent split from kidneyinfecting sphaerosporids [18].

Another myxozoan that is potentially participating in some cases of SBI as it is capable of invading the swim bladder and other organs via the vasculatory system, is the malacosporean Buddenbrockia sp. Small parasite stages, similar to initial stages of infection of Tetracapsuloides bryosalmonae Canning et al., 2002 in the gills and the blood of salmonids [27-29] were found associated with blood vessels in different organs of carp as well as in the gill lamellae. Using TEM, high numbers of intracellular parasites were detected in the pillar cells of the gills and in the endothelium of blood vessels of different organs of SBI carp [22,30,31]. It was suggested that these parasite stages belong to $S$. dykovae [30,31]. However, the related electronmicrographs show that they represent cell doublets that contain sporoplasmosomes inside their primary cells, which are often membrane-associated. 
Both features are characteristics that clearly link these cells to intrapiscine proliferative stages of the class Malacosporea, including the genus Buddenbrockia [32]. As the location of the parasites in the present study is identical with that of these previous reports, it can be assumed that they refer to Buddenbrockia sp. However, since the biodiversity of malacosporeans in cyprinids in Central Europe is unexpectedly high [33] and changes may have occurred over the last 20 years with regard to environmental factors such as water quality and temperature, thereby altering conditions for parasites and invertebrate hosts, other malacosporeans may well have been involved in these passed cases and may be contributing to present SBI outbreaks.

T. bryosalmonae is known to cause substantial proliferation of the host's white blood cells resulting in a granulomatous inflammatory reaction, predominantly the kidney and in the spleen, thus causing a severe condition, proliferative kidney disease, PKD, in salmonids $[34,35]$. Similarly, in the present study, we noted an inflammatory reaction including some degree of swelling of the kidney, spleen and liver in carp infected with large numbers of Buddenbrockia sp. This indicates that Buddenbrockia sp. may be responsible for a general immunological response rather than swim bladder-specific changes. This could potentially worsen an immunecompromised condition caused by high numbers of S. dykovae in the swim bladder or vice versa. While the order of appearance of the two parasites has yet to be resolved, considerable swelling of all haematopoietic organs has been reported in a number of SBI cases $[3,36,37]$ with myxozoan blood stages misidentified as Haemogregarina cyprini in [36], while S. dykovae infection is usually characterised by swelling of only the kidney [10].

While Buddenbrockia and especially S. molnari likely represent an important co-factor or pre-condition for developing SBI in carp, at the sites investigated in this study, we could clearly exclude other myxozoans as causative or co-causative agents of SBI as they were restricted to wellisolated plasmodia in the connective tissue of the swim bladder (T. hovorkai) or occurred in very small numbers (all other myxozoans).

There is considerable evidence that the epizootics of SBI vary according to the fish rearing systems used, e.g. $[31,38]$. We tried to compare the myxozoan species composition in pond systems that are similar with regard to their sediment types, as well as their culture, stocking and harvest techniques. In one case [31], two manifestations of SBI were differentiated depending on the method of carp fry culture and related to the presence/absence of intracellular malacosporean developmental stages in these fish. The authors reported heavier SBI pathology in carp reared in cages when compared with a sediment-associated carp population. We found that bryozoans frequently settle hard surfaces such as branches, stonewalls, pipes and aerators. The bryozoan Plumatella repens serves as host for Buddenbrockia sp. [39] and carp in floating cages or ponds with stone walls demarking their edges may thus be more prone to develop a Buddenbrockia-related SBI when compared with ponds that offer exclusively muddy sediments with a different invertebrate microfauna for myxozoan life cycle completion.

It would be of considerable importance for SBI management strategies to determine and confirm the invertebrate hosts of $S$. dykovae and S. molnari, as previous life cycle data on these species are scarce [40] and have to be treated with caution $[15,18]$. S. dykovae and S. molnari belong to the Sphaerospora sensu stricto phylogenetic clade [41] which is characterised by several extraordinary characteristics such as extremely long inserts in the SSU rDNA gene region and a currently unknown putative invertebrate host group [42,43]. However, the elucidation of myxozoan life cycles is based on the time-consuming screening of species-rich invertebrate communities in aquatic habitats. A different approach that could lead to a better understanding of the contribution of S. dykovae, S. molnari and Buddenbrockia sp. to SBI would be to determine when and where these parasites are present in the environment and to mirror the results from environmental screening with the course of the infections and the disease condition in fish, throughout the year, similar as performed for the marine myxozoan Ceratomyxa puntazzi Alama-Bermejo et al. 2011 [44]. With emerging numbers of $S$. molnari blood stages, we urgently need to improve our scarce knowledge regarding the parasite's preferred aquatic habitat, the periods of host infection, proliferation mechanisms in the host, the interplay with S. dykovae in the course of SBI and other pathological effects high numbers of $S$. molnari may have on common carp in Central European Aquaculture facilities.

\section{Conclusions}

The present study provides the first evidence that more than one myxozoan species may be involved in the etiology of SBI of common carp, depending on site, culture system setup and disease severity. Using, for the first time, molecular diagnostics to identify the pathological agents of SBI that belong to the Myxozoa, we were able to clarify ambiguities and misidentifications of proliferative myxozoan stages that occurred in the past, when SBI agents were analysed exclusively on the basis of their morphology and by relating life cycle stages based on experimental transmissions. We determined a strong correlation between high numbers of $S$. molnari proliferative stages and mild to severe SBI pathology, while only severe cases were characterised by large, proliferative swim 
bladder stages of $S$. dykovae, the species previously ascribed to SBI in common carp. We have noted emerging numbers of $S$. molnari blood stages at various carp culture sites, possibly in relation to rising water temperatures. While this leads us to predict increased re-occurrence of SBI cases in Central Europe in the near future, it cannot be excluded that further problems will emerge as $\mathrm{S}$. molnari has also been related to eye, gill and skin pathology in common carp. It is thus of special importance to advance our scarce knowledge on the life cycle, transmission and development of $S$. molnari in common carp.

\section{Competing interests}

The authors declare that they have no competing interests.

\section{Authors' contributions}

ASH conceived and designed the study. ASH, AH and EE coordinated its design and execution and were responsible for the collection of all samples from fish. ASH, SP and HP performed the molecular analysis. ASH drafted the manuscript and all authors read and approved its final version.

\section{Acknowledgments}

We thank the staff and students from the Institute for Veterinary Medical Research and the Institute of Parasitology of the Czech Academy of Sciences, which helped with the collection, transport and dissection of carp. We are grateful for the contribution of various fish farmers and fish farming associations for collaboration and for supplying fish, often without charge. We furthermore acknowledge the following research funding sources: European Commission (ModBiolin, FP7-REGPOT-2012-2013-1), Czech Science Foundation (505/12/ G112), Czech Academy of Sciences (Program for International Collaboration, M200961205) and Hungarian Scientific Research Fund (OTKA Nr. K112301).

\section{Author details}

${ }^{1}$ Institute of Parasitology, Biology Centre of the Academy of Sciences of the Czech Republic, Branišovská 31, České Budějovice, Czech Republic. ${ }^{2}$ Faculty of Sciences, University of South Bohemia, Branišovská 31, České Budějovice, Czech Republic. ${ }^{3}$ Institute for Veterinary Medical Research, Centre for Agricultural Research, Budapest, Hungary.

Received: 1 July 2014 Accepted: 17 August 2014

Published: 28 August 2014

\section{References}

1. Kovács-Gayer E: Histopathological studies on protozoan swimbladder inflammation of common carp fry. Parasitol Hung 1983, 16:39-46.

2. Waluga D, Budzynska H: Sphaerospora invasion as the cause of a massive mortality in carp populations. Gospodarka rybna 1980, 7:5-7.

3. Molnár K: Renal sphaerosporosis in the common carp Cyprinus carpio L. J Fish Dis 1980, 3:11-19.

4. Körting W: Protozoan parasites associated with swim-bladder inflammation (SBI) in young carp. Bull Europ Ass Fish Pathol 1983, 2:25-28.

5. Kovács-Gayer E, Csaba G, Bekesi L, Bucsek M, Szakolczai J, Molnár K: Studies on the protozoan etiology of swim bladder inflammation in common carp fry. Bull Europ Ass Fish Pathol 1982, 2:22-24.

6. Körting W, Hermanns W: Myxosporidien-Infektionen in der Niere des Karpfens (Cyprinus carpio L.) aus niedersächsischen Teichwirtschaften. Berl Münch Tierärztl Wochenschrift 1984, 97:255-259.

7. Molnár K, Kovács-Gayer E: Experimental induction of Sphaerospora renicola (Myxosporea) infection in the common carp (Cyprinus carpio) by transmission of SB-protozoans. J Appl Ichthyol 1986, 2:86-94.

8. Holland JW, Okamura B, Hartikainen H, Secombes CJ: A novel minicollagen gene links the cnidarians and myxozoans. Proc Biol Sci B 2011, 278:546-553.

9. Csaba G: An unidentifiable extracellular sporozoan parasite from the blood of the carp. Parasitol Hung 1976, 9:21-24.

10. Lom J, Dyková I: Sphaerospora renicola n. sp., a myxosporean from carp kidney and its pathogenicity. Parasitol Res 1982, 68:259-268.
11. Molnár K: The occurrence of Sphaerospora renicola K-stages in the choroidal rete mirabile of the common carp. Folia Parasitol 1993, 40:175-180

12. Lom J, Dyková I, Pavlásková M: "Unidentified" mobile protozoans from the blood of carp and some unsolved problems of myxosporean life cycles. J Protozool 1983, 30:497-508.

13. Körting W, Kruse P, Steinhagen D: Development of "Csaba cells" in experimentally infected Cyprinus carpio. Angew Parasitol 1989, 30:185-188.

14. Molnár K: Evidence that C-blood protozoa of the common carp are stages of Sphaerospora renicola Dyková et Lom, 1982. Bull Eur Ass Fish Pathol 1988, 8:3-4.

15. Holzer AS, Bartošová P, Pecková H, Tyml T, Atkinson S, Bartholomew J, Sipos D, Eszterbauer E, Dyková l: 'Who's who' in renal sphaerosporids (Bivalvulida: Myxozoa) from common carp, Prussian carp and goldfish - Molecular identification of cryptic species, blood stages and new members of Sphaerospora sensu stricto. Parasitology 2013, 140:46-60.

16. Holzer AS, Sommerville C, Wootten R: Molecular relationships and phylogeny in a community of myxosporeans and actinosporeans based on their 18S rDNA sequences. Int J Parasitol 2004, 34:1099-1111.

17. Holzer AS, Stewart S, Tildesley A, Wootten R, Sommerville C: Infection dynamics of two renal myxozoans in hatchery reared fry and juvenile Atlantic cod Gadus morhua L. Parasitology 2010, 137:1501-1513.

18. Eszterbauer E, Sipos D, Forró B, Bartošová P, Holzer AS: Molecular characterization of Sphaerospora molnari (Myxozoa), the agent of gill sphaerosporosis in common carp Cyprinus carpio carpio. Dis Aquat Organ 2013, 104:59-67.

19. Ter Höfte BB, Körting W, Lehmann J: C-und K-Protozoen, Endoparasiten unsicherer systematischer Zuordnung bei jungen Karpfen Cyprinus carpio L Derzeitiger Wissensstand und bildliche Dokumentation. Fisch und Umwelt 1984, 13:89-99.

20. Molnár K: Gill sphaerosporosis in the common carp and grass carp. Acta Vet Acad Sci Hungar 1979, 27:99-113.

21. Lom L, Dyková I, Pavlásková M, Grupcheva G: Sphaerospora molnari sp.nov. (Myxozoa:Myxosporea), an agent of gill, skin and blood sphaerosporosis of common carp in Europe. Parasitology 1983, 86:529-535.

22. Lom J, Dyková I: Intracellular parasites of unknown taxonomic position in gills of common carp Cyprinus carpio. Dis Aquat Org 1993, 16:235-237.

23. Rohlenová K, Morand S, Hyršl P, Tolárová S, Flajšhans M, Šimková A: Are fish immune systems really affected by parasites? An immunoecological study of common carp (Cyprinus carpio). Parasit Vectors 2011, 4:120.

24. EAA Report 12/2012: Climate change, impacts and vulnerability in Europe 2012. http://www.eea.europa.eu/media/publications/climate-impacts-andvulnerability-2012.

25. Mikheev VN, Pasternak AF, Valtonen E: Increased ventilation by fish leads to a higher risk of parasitism. Parasit Vectors 2014, 7:281.

26. Dyková I, Lom J, Körting W: Light and electron microscopic observations on the swimbladder stages of Sphaerospora renicola, a parasite of carp (Cyprinus carpio). Parasitol Res 1990, 76:228-237.

27. Morris DJ, Adams A, Richards RH: In situ hybridisation identifies the gill as a portal of entry for PKX (Phylum Myxozoa), the causative agent of proliferative kidney disease in salmonids. Parasitol Res 2000, 86:950-956.

28. Holzer AS, Sommerville C, Wootten R: Molecular studies on the seasonal occurrence and development of five myxozoans in farmed Salmo trutta $\mathrm{L}$. Parasitology 2006, 132:193-205.

29. Grabner DS, El-Matbouli M: Tetracapsuloides bryosalmonae (Myxozoa: Malacosporea) portal of entry into the fish host. Dis Aquat Organ 2010, 90:197-206.

30. Voronin VN: PKX-like organism in common carp during swim bladder inflammation: further evidence of an association with the myxosporean Sphaerospora renicola. Bull Europ Ass Fish Path 1993, 13:127-129.

31. Voronin VN, Chernysheva NB: An intracellular gill parasite as the possible causative agent of mortality during swim-bladder inflammation in common carp, Cyprinus carpio L. J Fish Dis 1993, 16:609-611.

32. Canning EU, Curry A, Feist SW, Longshaw M, Okamura B: A new class and order of myxozoans to accommodate parasites of bryozoans with ultrastructural observations on Tetracapsula bryosalmonae (PKX organism). J Eukaryot Microbiol 2000, 47:456-468.

33. Bartošová-Sojková P, Hrabcová M, Pecková H, Patra S, Kodádková A, Jurajda P, Tyml T, Holzer AS: Hidden diversity and evolutionary trends in malacosporean parasites (Cnidaria: Myxozoa) using molecular phylogenetics. Int J Parasitol 2014, 8:565-577. 
34. Ferguson HW, Needham EA: Proliferative kidney disease in rainbow trout Salmo gairdneri Richardson. J Fish Dis 1978, 1:91-108.

35. Clifton-Hadley RS, Bucke D, Richards RH: A study of the sequential clinical and pathological changes during proliferative kidney disease in rainbow trout, Salmo gairdneri Richardson. J Fish Dis 1987, 10:335-352.

36. Kudryashova YV, Naumova AM: Effect of Haemogregarina cyprini on carp. Veterinariya 1978, 4:76-78.

37. Al-Samman A, Molnár K, Székely C, Reiczigel J: Reno-, hepato- and splenomegaly of common carp fingerlings (Cyprinus carpio L.) diseased in swimbladder inflammation caused by Sphaerospora renicola Dyková et Lom, 1982. Acta Vet Hung 2003, 51:321-329.

38. Odening $\mathrm{K}:$ On the alternation of generations in myxosporidians/ actinomyxidians (Myxosporidia). Zool Anz 1991, 226:237-252.

39. Grabner DS, El-Matbouli M: Experimental transmission of malacosporean parasites from bryozoans to common carp (Cyprinus carpio) and minnow (Phoxinus phoxinus). Pararsitology 2010, 137:629-639.

40. Molnár K, El-Mansy A, Székely C, Baska F: Experimental identification of the actinosporean stage of Sphaerospora renicola Dyková \& Lom 1982 (Myxosporea:Sphaerosporidae) in oligochaete alternate hosts. J Fish Dis 1999, 22:143-153.

41. Jirků M, Fiala I, Modry D: Tracing the genus Sphaerospora: rediscovery, redescription and phylogeny of the Sphaerospora ranae (Morelle, 1929) n. comb. (Myxosporea, Sphaerosporidae), with emendation of the genus Sphaerospora. Parasitology 2007, 134:1727-1739.

42. Holzer AS, Wootten R, Sommerville C: The secondary structure of the unusually long $18 \mathrm{~S}$ ribosomal RNA of the myxozoan Sphaerospora truttae and structural evolutionary trends in the Myxozoa. Int J Parasitol 2007, 37:1281-1295.

43. Bartošová P, Fiala I, Jirkủ M, Cinková M, Caffara M, Fioravanti ML, Atkinson SD, Bartholomew JL, Holzer AS: Sphaerospora sensu stricto: taxonomy, diversity and evolution of a unique lineage of myxosporeans (Myxozoa). Mol Phylogenet Evol 2013, 68:93-105.

44. Alama-Bermejo G, Šíma R, Raga JA, Holzer AS: Understanding myxozoan infection dynamics in the sea: seasonality and transmission of Ceratomyxa puntazzi. Int J Parasitol 2013, 43:771-780.

doi:10.1186/1756-3305-7-398

Cite this article as: Holzer et al:: Molecular fingerprinting of the myxozoan community in common carp suffering Swim Bladder Inflammation (SBI) identifies multiple etiological agents. Parasites \& Vectors 2014 7:398.

\section{Submit your next manuscript to BioMed Central and take full advantage of:}

- Convenient online submission

- Thorough peer review

- No space constraints or color figure charges

- Immediate publication on acceptance

- Inclusion in PubMed, CAS, Scopus and Google Scholar

- Research which is freely available for redistribution 